University of Louisville

ThinkIR: The University of Louisville's Institutional Repository

Electronic Theses and Dissertations

1932

\title{
The electrodeposition of chromium-nickel alloys.
}

Richard James Whelan 1910-2000

University of Louisville

Follow this and additional works at: https://ir.library.louisville.edu/etd

Part of the Chemistry Commons

\section{Recommended Citation}

Whelan, Richard James 1910-2000, "The electrodeposition of chromium-nickel alloys." (1932). Electronic Theses and Dissertations. Paper 1926.

https://doi.org/10.18297/etd/1926

This Master's Thesis is brought to you for free and open access by ThinkIR: The University of Louisville's Institutional Repository. It has been accepted for inclusion in Electronic Theses and Dissertations by an authorized administrator of ThinkIR: The University of Louisville's Institutional Repository. This title appears here courtesy of the author, who has retained all other copyrights. For more information, please contact thinkir@louisville.edu. 


\title{
UIIVARIT or IOUISVI.T.
}

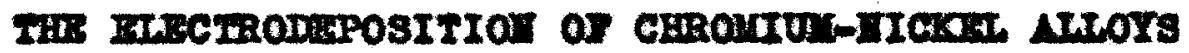

\author{
4 DLeeertatlea \\ subutited to the Jecult

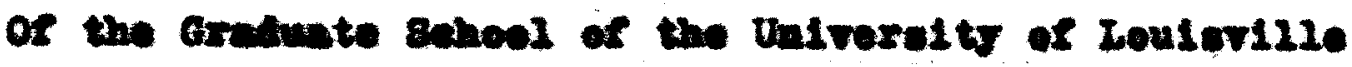 \\ In Partin Fulfiliment of the \\ Requilramente for the Degree \\ of lievtex of Betenes
}

Dopartument of Chontety

2y

RICHARD JANOS ERRAN, JR.

Tear

1938 


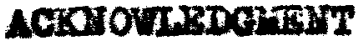

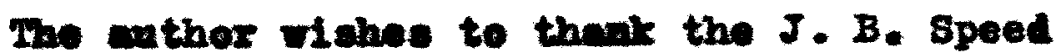
Foubdetion for the crud of the Speed Grelusto

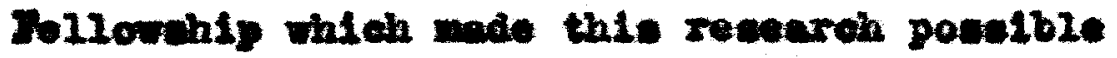
and 1 e elnowloder the helprul souletenee and vanbie areotion of D. Robort Crats Bract. whe dirosted thit imesticotion. 
TABIS OP CONmBYS

Page

Introduction $\ldots \ldots \ldots$

Thooretleal _.............. 6

Effeot of Concentration - . - - 7

Iffect of Current Density - - - - 10

Hydrogen D1waherge and Orervoltage - 12

Polarisation _........... 17

Bffect of Anodes - . - . . . 18

Conelusion - . . . . . . . 21

Rrgerimentel

Prelinimary forimental - . . - 22

llaterials and Apparatus ......- 24

rinal Bxperimental _........ 27

Condualon ................ 41

Blbllography _..............43 
Irrzanucrion 
Chrem-nielel allers and steels have of recont yeare been produced ecmerelally. They heve the propextiee of withotanding extreme conditions of teapere-

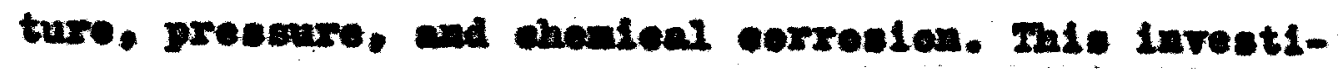
gatlon we vadertaken with the lien of produclag -lectrodepositod allogs of alokel and ehromitu on Iros and othor bave wetals. Thoes doposted allors chould produce a nom-poreus wurfece which would be eapabie of ithotanding the deleterious effocte of rumes. rapers and chonleals which esuce destruetion of alekel and chronlun doposits. The alleg should have the cdditional properties of hardmese and cbrasion reelstane.

It has not been considered possible to deposit alloge of nlekel and chromim, beeause alekel bas been ceposted from noutral or el1ghtly aeid bolutions, while ehromiun is deposited from distinetiy acld solutions.

It Is ouls of recent years that chromiun has been cuccosarully electrodeponted comerelally, ylelding - curface hlghly reoletant to atmoupherie eorroslon and alse having characteristies or extreme hardness. 
The disadvantege enecuntered in electrodoposited ehroniv is poresity, and an intermediate layer of seme wetel which w11 protest the underlying enrface fram corroston is therefore neceseary. Succesurul ohromive depoel to have been made over intermediate coats of copper and alekel on the bace meter Iron.

An electrodeposited alekel aurface presents : bich luster. elmiler in rerlecting quallty to ofiver and at the wave tim ate al a protective costing for iron or steel. It is extenolvely ueed for ormam mental purposes. The corresion resisting properties or niekel dopend on the Impervioue quallty of the wurfave which chould be .001 " thick in order to protect stoel.

Allore haring ehroniw as one constituent tend to realet the correctre setion of gaves and 11quids, unlese thewe allog: contaln a large percentege of another metal easily attecked by the corrosive agent. The purpose of the eleetrodeposition of an alloy of ohreatum-aickel direetly on the lron or copper base 1. to reduce the porosity, while at the sam time retalning the corrosioni-reateting qualities of chroulus. In this maner, noleture and destruetire colds may be prevented from ponetrating the outer warface and attacking the underlying netwl. 
Fach of these wetale hes been co-dopoelted with othor motale, but not wth each other. A number of nlakel alloye have been eleetrodeposited, awong then belug, nickel-eopper (1), niekel-tin (2), niekel-1ron (3), nickel-eobalt (4), and aldrel-sine (5).

In all cases exeopt the last mentloned, the wotal content of the deposits varies with the ratio of wotals In colution, whon the surrent density is hich. Hiekelwine allore are unlque, In that, al though the selution contains en exces of alokel, the depoelt oontains wore sine then alekel.

IIlekel and Iron were atmiteneouely deposited by Leuchter (6) from $\mathrm{HSO}_{4}$ and $\mathrm{FeSO}_{4}$, ueling the latter In expoes.

II licel has been deposited almul teneouly with other motals in the form of the termary alloys, Cu-HI-Zn (7), Cu-H1-Sn (8), and De-H1-Co (9).

Ixperimenting on obromium-iron elloye, Fuseya and savak1 (10) found that obromie acid and Iron asite remultod in a poor depoelt, and therefore, they ueed - bath sompesed of the alxed sulfates, to which was addod on oxeese of eulfurie cold. It was found thet by Inoreseing the eurrent density and lowering the tempereture, the percentage of ahronium was inereased. 
Stomons and Falgice (21) have patented a procese by which aldkel and ehromiun ean be elmultaneously. deposited from a wolten bath composed of chronle oxide (15 parts). borax ( 40 parts). oodiw metaphosphate (50 parte) and the addition of a niekel salt. The Bempereture is $950^{\circ} \mathrm{C}$. and the eurrent density about 1000 aups./aq. m. of eathode surface.

In 1905, the firat eleetrodeposition of ehromium was earried out by Carreth and Curry (12), who showed that the reduction of chromie seld $\left(\mathrm{CrO}_{3}\right)$ at a high current density ylelded metallie chroniw, and thet salte, weh as sulfates, inproved the character of the plate. Tho flret bath to arouse comereiel interest was that of Saxgent (13) in 1920, and it 1s essentially the same as thet used in moderp plating. The commonily used bath for ohromlun deposition is composed of $2.5 \times \mathrm{CrO}_{3}$ and about 2.5 ane of $\mathrm{Cr}_{2}\left(\mathrm{SO}_{4}\right)_{3}$ per Ifter, using a esthode eurrent density of 12-40 anps./sq. de. and lead anodes. Sehnelderind sumarizes the existing petents desling with chromium deposition and states that no single patent or group of patents can control the depostion of ehromiun from shromle acid bathe (24).

The firat oomereiel attempt to deposit niekel electrolytieally, was ande by Adane (15) In 1865, onploying a solution of $\mathrm{HLCl}_{2}$ and anodes of east niekel. 
At present, the ctandard bath for comperelel alckel deposition is eomposed of the single salt, $\mathrm{HLO}_{4} \cdot 6 \mathrm{H}_{2} \mathrm{O}$, with $\mathrm{HICl}_{2} \cdot 6 \mathrm{H}_{2} \mathrm{O}$ added to Inerease enode corrosion and $\mathrm{H}_{3} \mathrm{BO}_{3}$ to regulate the asldity. Anodes of east niekel or eleetrolytie niekel are used, and these dissolre with high enode effleieney in the presonee of chlorides. 


\section{THORTTICAT}

2we metwle ean be simitaneously eleetrodepesited. provided the eleetrode potentiale of these two motals in contast with solutions of thelr lons are the same.

The noxmal eleetrode potentials of niekel. chromiun, and hydrogen are shown in Table I. (16)

\section{TABLE I}

HORUAI EIIFCTROME POTEWTIAIS

\begin{tabular}{|c|c|c|c|}
\hline & Hy drogen & I. Calanel & Abeolute \\
\hline Cx & -0.47 & -0.75 & -0.19 \\
\hline $\mathbf{n L}$ & -0.20 & -0.48 & 0.08 \\
\hline $\mathbf{B}_{2}$ & 0.00 & -0.283 & 0.277 \\
\hline
\end{tabular}

The Dernst formula for the determination of the electrode potential is derived from the coneept of ormotie and solution presoures. The osmotie pressure 1s the preseure exerted by the netal lons, or their cendency to pase from the lonle to the atomie state and the colution pressure is the tendeney of the motal to dissolve or to pass from the atomile to the lonie atete.

$$
E=\frac{R T}{\mathrm{Tr}} \ln \frac{\mathrm{kC}}{\mathrm{P}}
$$

Where the solution is normal with reference to the partieulax lons, the equation becomes

$$
\mathrm{B}_{0}=-\frac{\mathrm{RT}}{\mathrm{MP}} \operatorname{In} \frac{\mathrm{P}}{\mathrm{T}}
$$


Subtracting, we obtain

$$
\begin{aligned}
& \mathrm{z}_{0} \mathrm{E}-\frac{\mathrm{RT}}{\mathrm{ir}} \mathrm{in} \mathrm{c} \text {. } \\
& E=\text { single electrodo potential } \\
& E_{0}=\text { normal electrode potential } \\
& \text { R - gas constant } \\
& T \text { = absolute temperature } \\
& \text { II valence of the metal } \\
& z \text { - Faraday constant }(90,540 \text { coulombs) } \\
& P=\text { electrolytio solution pressure } \\
& k \text { - proportionality constank } \\
& c=\text { molar lanic eoncentration }
\end{aligned}
$$

If the two metals are to deposit eimultaneously, the values of I for both must be the same. The eleetrode potential is a funetion of many eomplex rariables. It is affeeted by concentration, current denelty, orervoltage, nolarization, temperature and eathodia alloy formation.

\section{EITEC' OF COMCENTRATIOH}

Aceording to equation ( 1 ), the aingle potential of a wetal will vary with coscentration. Dilation and the formation of complex salts both affect the 1onis eoneentratien. Dilution is not recomended in niekel-chromium deposition, sinee both metels are normaliy deposited from colutions of bigh metal aalt content. The motal lon concentration is greatly 
reduced by use of complex ants, and at the high ourzent deneltioe noceseary for setieraetory chromium depostion, the colution rould raplaly become inpoverIthed in chroutu ions.

The sodiun or potassium chromium oyanides are unknown and therefore, cyanides as emplexes are not coneidered prwetien, al though $\mathrm{HI}(\mathrm{CH})_{2}$ existe. The correpponding complex salts of these netale are not comon; and wille chromates and dichromates are connon, the correspunding niekel salts are unknown. Variation of concentration by dilution and complex lan formatics are not therefore practieal wethode of bringing the potentiale togother.

By inereasing the eurrent deneity, the potentials of two wetals can be made to approaeh oach other; and benee, sine the difference between the ingle electrode potentials of III $(-0.20)$ and $C r(-0.47)$ is oniy 0.27 rolte. these potentials should becove equal at highor current densities. The eurrent density-potential curves are given in P1g. I. The values for ahronium (17) show that at hleh ourrent densities, the curre bends distinetis to the right. The ourve for niekel (18), while only arailable for low current densities, because experimentel work has been earried on only at these 10 w 
FIG. I

CURRENT DENSITY - DISCHARCE POTENTIAL CURVES

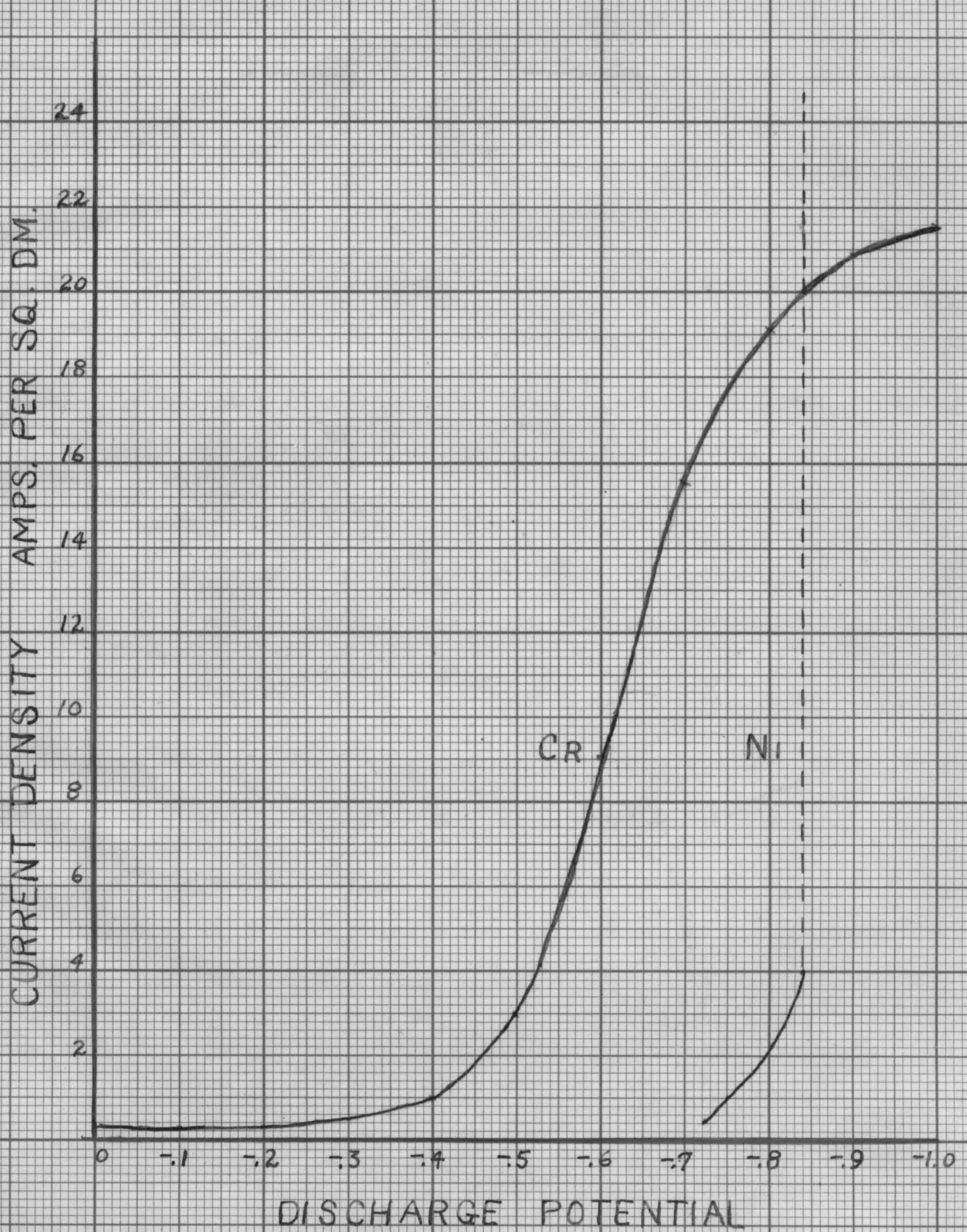


current donstitee, whewe that if the valeos are extrom

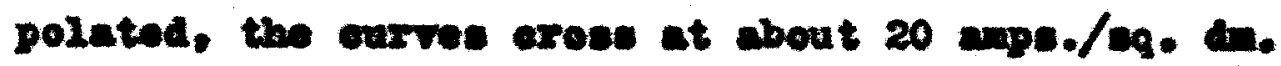
This would lead ane to expect that at hich ourront denelt1es, the two netale might be almultaneouly depost tod.

\section{BFFECT OF CURBSUT DEAISITY}

There 1s wide verlanee in the effeet of eurrent denelty on the two metale. In $\mathrm{HSO}_{4}$ volutions, an Inereaned current donelty causes a greater electron flow, resulting in a more rapid deposition of niakel. In $\mathrm{CrO}_{3}$ solutions, a $10 \mathrm{w}$ current density morely offects - partial reduetion of CrVI to CrIII. bat does not complete the reduction to the metellie state. It is only when the current density excesds a polnt at which the dicoharge potential of chromiun becomes equal to that of hydrogen that estal is deposited.

Thlo variable, current denelty, is not so important in nlekel deposition, for a good depost can be obtalned from 0.5 - 10.0 amps./eq. dn., and, the temperature belag held constant, an inerease in current denalty will give Iiner grained deposite, elnce now melel are formed more rapidly, and those alroady formed have no perlod of growth. Belng more electromegative than hydrogen and also belng deposited from 
an seld colution, hrerogen is erelred with the alekel which tond" to cive e fino-grainod, though brittle plete.

Selneidowind (19) whowe that increaced ourrent donsity results In inoreaced current effleleney for ceveral rat1os of $\mathrm{Cr}^{\mathrm{I}} / \mathrm{sO}_{4}$, and his reaulte shor that the range for bright ehromiun depost te is widened as the wurrent donolty inoreases. Gurrent density has on effeet on the formation of CxIII, the maximan wount of which is formed at low ourrent denstitles. The type of naterial used as cathode has an effeet on CxIIIas studied by Iukens (20), who found thet alekel as eathode materlel formed the least anount of CxIII. copper nore, and lead the largest anount.

The renetion in the eeparate deposition of niekel and enronim it as followe:

$$
\begin{aligned}
& \mathrm{Cx}^{++}+20 \rightarrow \mathrm{Cx}^{\circ} \\
& \mathrm{HI}^{++}+20 \rightarrow \mathrm{HI}^{\circ}
\end{aligned}
$$

or, in other rords, the deposition of elther netal deponds on the precence of bivalent lons. In the ense of alekel, the bivalent lons are precent in the colution of $\mathrm{HSO}_{4}$, whlle in $\mathrm{CrO}_{3}$, the hexavalent lone mast be reduesed to the blvalent state. Liebrefoh (21) eanues the existence of an equilibrium

$$
\mathrm{Cr}^{++}+2 \mathrm{HH}^{+} \rightleftharpoons \mathrm{Cr}^{+++}+\mathrm{H}_{2}
$$


and aves thls hrothesis to explain the orolution of uriregen with the robution of valenes. The potentiale of the two proeesese are

$$
\begin{aligned}
& \mathrm{Cr}^{++}+\rightleftharpoons \mathrm{Cr}^{++} \quad-0.412 \text { volte and } \\
& \mathrm{Cr}^{++}+20 \rightarrow \mathrm{Cr}^{\circ} \quad-0.557 \text { rolte. (22) }
\end{aligned}
$$

Aecording to sergent (23), deponition of ehronlun Irom $\mathrm{CrO}_{3}-\mathrm{Cr}_{2}\left(\mathrm{SO}_{4}\right)_{3}$ solutions at moderate ourrent dongltios, Is accompanied firet by the fornstion of - Film on the esthode with a mearly moutral colution In conteot with it\} while at higher current denolties, - I1In forme and hydrecen is evolved.

In goneral, st high current densities, one would expect the pessibility of elmulteneoue deposition of chromitu and nlakel. The efflelency, due to the erolution of hydrogen, would be $20 \mathrm{w}$, and the reoulting depoeite as be brittie, due to adsorbed hydrogen. Inoressed ourrent densities would inoreses the chromiun content to a value where the current densitydischarge potential curres erose each other, and abore that point ane would expect an inereased amount of alekel in the deposit.

\section{FIPROGEI DIBCHARGE AND OVERVOLTACE}

Fable $I$ showe that both alekel and ehroulum are 0.2 and 0.47 rolts reopectively, ebore hydrogen in the eleetrochenteal ceries, and when the deposition is 
carried out frem wolutiong, mormal with reapest to motal 10ne, there is a preforential disehnre of hydrogen, einoe a lowex potentiel is required to doposit hudrogen then is neceseary to deposit elthor metal. Therefore, gaselng oceure elmitancously with the cepoeltion of elther wetal. This large rolune of hydrogen, which requires eonelderable onoroy. eaumed - Ion eathode effleleney for doposition.

IIfkel ean be doposited Ixom colutions of $10 \mathrm{~W}$

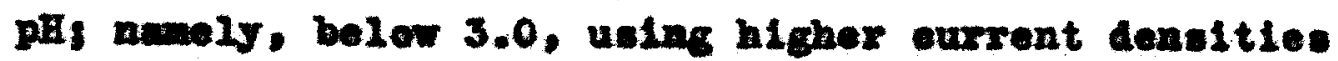
then with colutions of comonly used ph $(5.5)$. The Inerensed aeld alde anode cerrosion but lowers the eurront officlengy to sbout $75 \%$ due to laxge anounte of kydrogen beling dlecharged (24).

The overvoltages of the two metal are given In Table II (25). These hydrogen overvol tages were meanured in $2 \mathrm{I} \cdot \mathrm{H}_{2} \mathrm{SO}_{4}$ saturated $\mathrm{w}$ th hydrogen.

TABIE II

HYTROCEI OVARVOLTAGES AT $25^{\circ} \mathrm{C}$

\begin{tabular}{|c|c|c|}
\hline C.D. in aflifamps. & Ms & 6 \\
\hline $\begin{array}{r}1 \\
10 \\
100 \\
2000\end{array}$ & $\begin{array}{l}0.663 \\
0.747 \\
1.048 \\
1.241\end{array}$ & $0.32 x$ \\
\hline
\end{tabular}




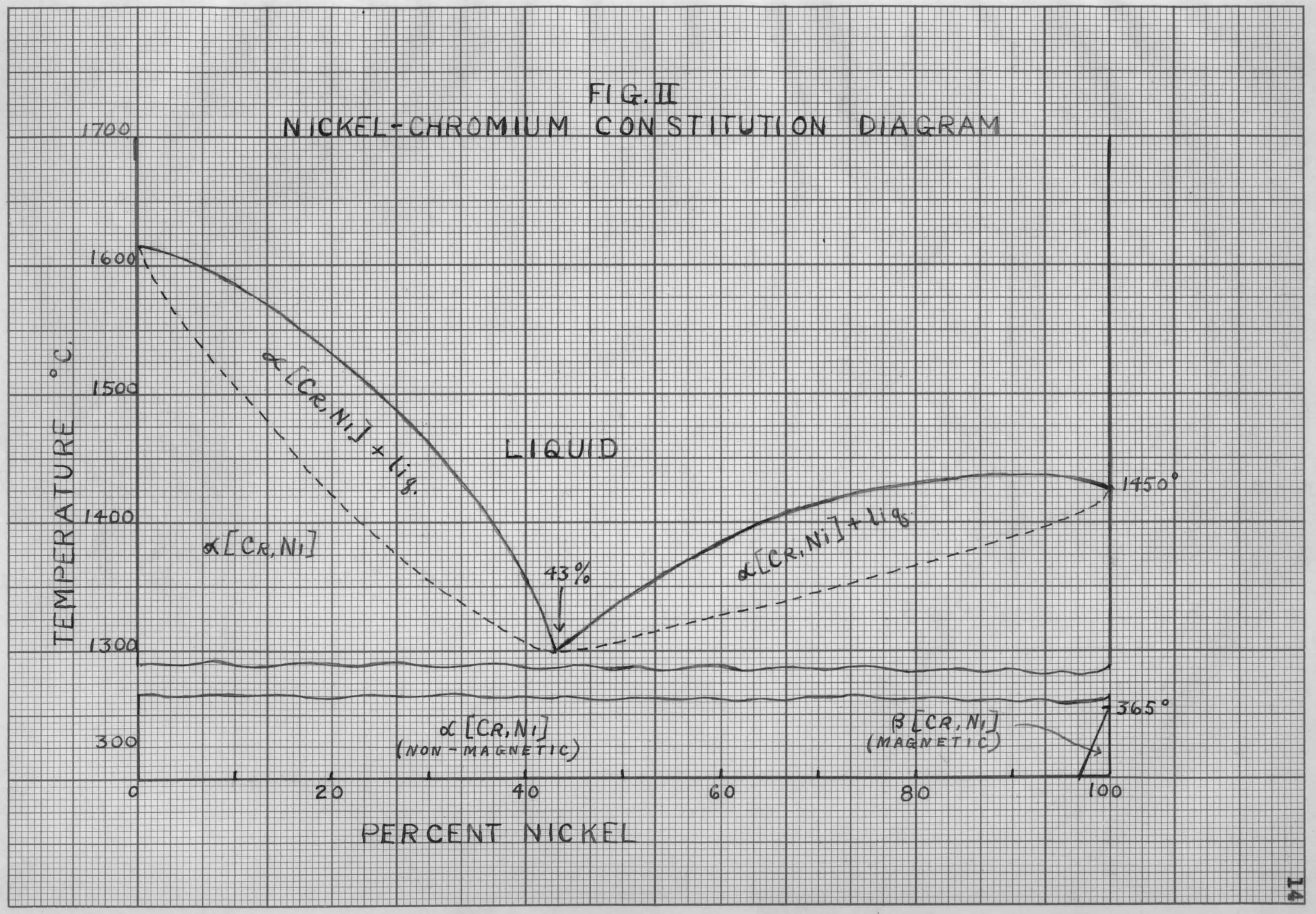




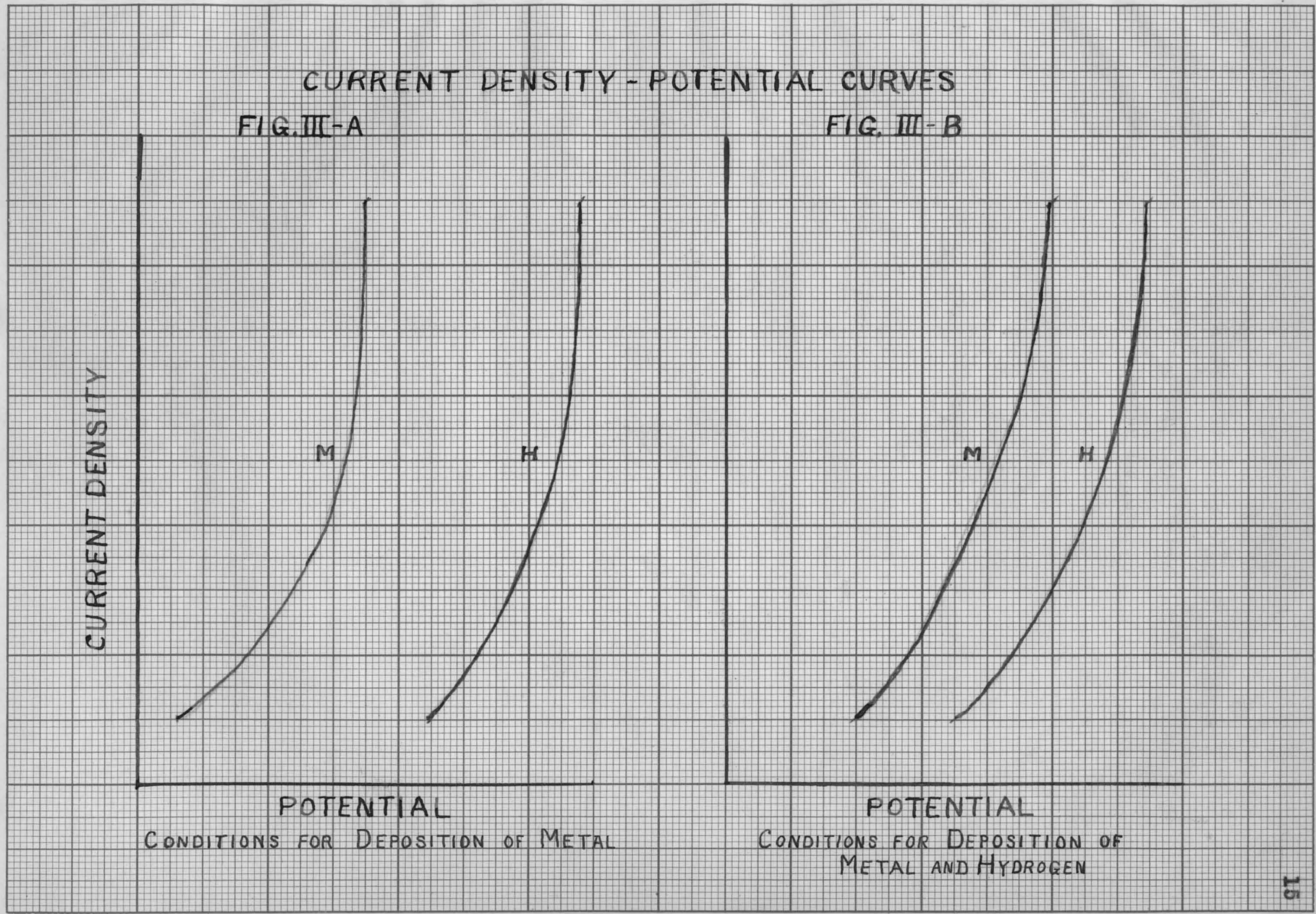


These velues show that for nidkel the overroltege inoreaces with eurrent donelty. Bo values are arallable for orerroltages of nlekel-chremiun alloyes but since the constitution diegram (Fig. II) Indieates that these netale form a ceries of solld colutions, the overveltage of the alloy is probably intersediate between that of niakel and that of chrealiun.

These values for orervoltage would ladloate thet there is a poesibility of depositing alekel from a bath of $10 \mathrm{w}$ pll and the elmultaneous deposition of the two wetals would be poselble, even though it is accompanled by a co-deposition of hydrogen.

Before hydregen 7111 be diseharged from a bolution, an electromotive force must be Impreesed whloh exceede the hydrogen overvoltage of the notal. Whether a metal, hydregen, or both will be deposited, depends on the ralues of $F_{n}$ and $I_{h}$ ae determined by Equation $I$, where F is the alngle electrode potential for the metal, and $\mathrm{F}_{\mathrm{h}}$ is the eingle clectrode potential for hydrogen. If I. I0 lese electronegatire than $F_{h}$, oaly metal will deposit, as in $\mathrm{Fig}$. III-A. If $\mathrm{I}_{\mathrm{m}}$ is nore electronegative than $B_{h}$ only hrdrogen 1111 be liberated, exeopt where $B_{h}$ plus the overvoltage is greeter than $F_{\text {. }}$

In Fig. III-B (26) the overvoltage of the metal for a given current censity, Io equal to that of the 
hydregens and bonee, the two w111 depost together. Ior it is alce poesible to obtain the sam relationulp for two metals, and in this annor form an alloy of these motale.

\section{POLARIzATIOI}

Polarisation nay be deflapd as a counter elestronotive fores eaused by the deplotion of mbetences usod in the reastion, sevtox than thay oan be replaced, or the formation of the products of the reastion faster than they can be remored.

The rate of depletion of lons in the region of the eathode veries with the eurrent density. reculting In on increase in polerisation, thus requiring a greater potential to obtain the desired current. Tho current donel ty-diecharge potential eurves (F18.I) wher that the curwe for alckel at high eurrent denaties lo $10 e s$ eleetronegative than the chromim curve. and ons reald expect the deposition of niekel from these potential curves alone, even though there wore no depolarizing extion. By depolerising one of the wetale, the discharge potential of the other netal is ande mearly equel to that of the depolarised metal. This depolarization caves the formation of an alloy and the two metals are precent eithor as a 
compound a solid solution. (27) The potentiel of a motal in a solution of Its lon changes with the comerntration of these lons, and the potential Inereases as the solution becames more dilutes but this ohange 18 not a direet funetion of the concentration ehange. If enrouive is depolarised by niekel, there 10 a posalbility of almal taneous deponition at a lower potential.

The eonstitution diagran for ohroniwn-nlekel alloye (IFig. II) whowe that niekel and enrentum form - complete geries of volid colutlons with alniman. The potential for raxying composition of the alloy world therefore be intermediate between those of the tro motale, and aimulteneous deposition would be expeeted.

\section{Hrinct of ANODEs}

In the deposition of wost notele, anodes of the zeopective metale are used in allog deposition. It is eustomary to use snodes of each metal or east anoden of the alloy in the ratio desired. For practieal alloy deposition, the composition of the beth must remaln constants and conequently, an anode of the two metals is necessary, wach that the metala will disselve in the ratio as they are renored from solution. 
In shronlum doposition, rarlous enodes have been Investigated (28). Mickel and Iros anodes becone passite in oxidizing solutiong. Chromiw In eteel renders it unfit for snode use, since it 18 too easily axidized in the $\mathrm{CrO}_{3}$ volution. Ferro-chromium and II-Cr slloys (Chromel, Nichrome, ete.) are worthlegs as anodes. In aleicel deposition, pure electrolytie nlekel becomes passive and much better resulte are obtalned by using east anodes with a mall emount of impurities. In order to ald anode corrosion, - solublo chloride 18 added preferably $\mathrm{HICl}_{2}+6 \mathrm{H}_{2} \mathrm{O}$, ance it hag the advantage of adding a common lon thus repressing he $\left(\mathrm{SO}_{4}^{--}\right)$, whlch, in eace of the alxed bath of $\mathrm{IISO}_{4}-\mathrm{CrO}_{3}$. Is in exeess of the prefereble ratio of $\mathrm{Cr}^{\mathrm{VI}} / \mathrm{SO}_{4}$ of $50-1$ as recomended by Saknotderind. (19)

Lead anodes for ehromium plating are less soluble at $10 \mathrm{w}$ temperatures but more soluble at high texperatures than Iron. Sehwerts (29) favored the use of ehroniva or ferro-chromiun enodes but Watts (28) found the anode offleleney was greater then the eathode effielency. The oarllest records of chromive depostion reveal that platinum anoden vere used. Placet and Bonnet (30) vere the first to mention the 
use of lead siodes. The theory, as held by sereral wthers, of the uservinese of lead anodes for the coridation of GrIII to CrVI, is that elther a chromate or an axide 1s rarmed on the lead, and this axidises the trivalent chroulan to the hoxaralent otete.

Since lead is not used to supply motel lone, the paesivity is very farorable to axidation and the malutenenee of equilibriw between CrIII and CxI.

If the anode erfieleney is low, the oathode erfieleney of the nlekel beth is dopreaned, due to inoreaned acidity, but thie theory does not apply under the conditions of this investigation in wioh insoluble lead anodes were neod. 
corrchosian

Guroulu and mickel hore not been prevlounly eleetrodoponted olmitaneoung fren equeour solutions.

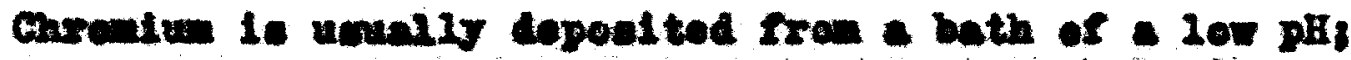
whil miakel is copost tod from a both with a pl of sbont 5.5 .

It chould be ponsible, however, to deposit thase ntale Irom an acld solution, weing a high eurrent dencity in the overroltage increanes of th current denulty, and the eurxent denofty-diceharge potential curves for niekel and chromiun eross at high eurrent denuties. The efrletency of depostion of the ntekel-ehronium alloy from an cold colutien would be 10, in to hydregen evelution. 
EoptrTtat. 


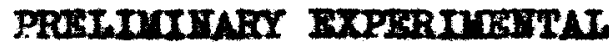

The purpow of this investigation was to attempt the simaltawoous dopostion of alloys of niakel and ohroniw from equeons solutione. There has been no pretious vork reported on this alley, and the experimontal work recelved iteelf into a otudy of (I) a oultable bath for deposition and (2) the best operating conditions.

Chrontun, as previously mentloned, had been plated from chromle celd colutions, but the electrodeposition of alakel has been limited to solutions of a pll of 5 , except in one cese mentioned. Thus, previous work suggested the ingrecticability of simultaneous deposition.

Blanry and terwary alleys have been succesafully deposited from oyanide solvtions and these solutions mogeted themedree for deposition of nickel-ohromim alloys.

Miekel cyanide was prepared when niakel ahlortde wes trosted with a copeentrated solution of KOH and excono KCI. It was found imposalble to propare a dovble sodium

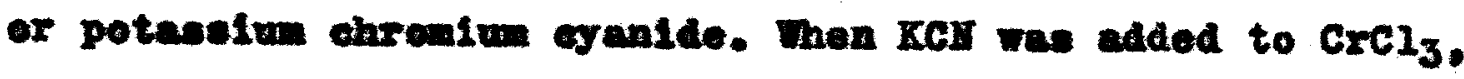
cyanogen wes evelved, but when wade allaline, $\mathrm{Cr}(\mathrm{OH})_{3}$ 


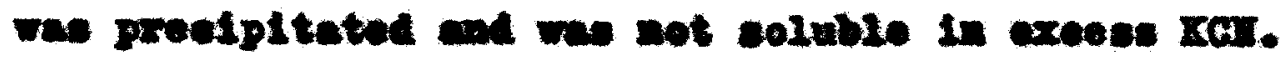

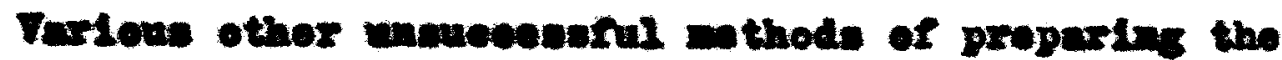

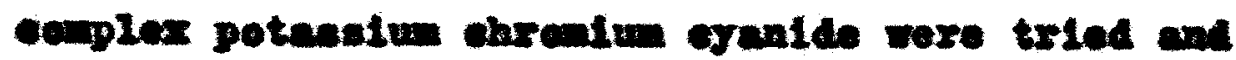

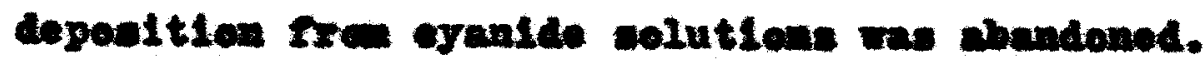

$A$ otendare alekel plating both to which were

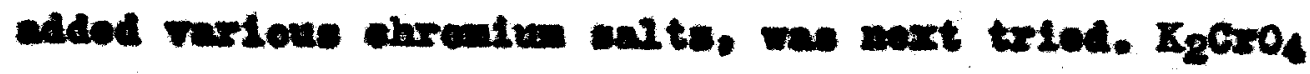
and $\mathrm{Cr}_{2}\left(\mathrm{SO}_{4}\right)_{5}$ were cadod os the ehrovium eal to. The coneontration of the combined bathe was!

$$
\begin{aligned}
& \mathrm{IISO}_{\mathrm{SO}} \cdot 6 \mathrm{H}_{2} \mathrm{O}-\mathrm{z}-140=\mathrm{N} \\
& \mathrm{Cr}_{2}\left(\mathrm{SO}_{4}\right)_{3}-\ldots, 120 \mathrm{~mol} \text {. }
\end{aligned}
$$

This colution wan made ald atth $\mathrm{H}_{2} \mathrm{SO}_{4}$, hoatod to $60^{\circ} \mathrm{C}$, and opereted at 3 rolte and $12.5 \mathrm{anp} / \mathrm{eq} . \mathrm{co}$. uelus ou cathodes and $\mathrm{Pb}$ anodes. The rewaiting deposit was a dull croy. Purther exporiments using this beth wedor raxylue conditions ald not give caticractory reaults, so no ehromitu was found in the deposit.

Ilekel oan be cuecensfully deposited from a colution of $\mathrm{HLSO}_{4}$ and $\mathrm{FICl}_{2}$, and chroutur is commerelally deposted from a selution of $\mathrm{CrO}_{3}$ therefore. the allor chovld, under proper contrel of conditions, be depoelted frem a mixed bath. A buth containing the combination was prepared ueling the following congentratlons:

$$
\begin{aligned}
& \mathrm{CrO}_{3}-\mathrm{C}_{-}-250 \mathrm{~m} / \mathrm{L} \\
& \mathrm{IISO} \cdot 6 \mathrm{H}_{2} \mathrm{O}-250 \mathrm{~m} / \mathrm{A} \text {. } \\
& \mathrm{HICl}_{2} \cdot 6 \mathrm{H}_{2} \mathrm{O} \text { - } 2.15 \mathrm{gm} . / 1 \text {. }
\end{aligned}
$$




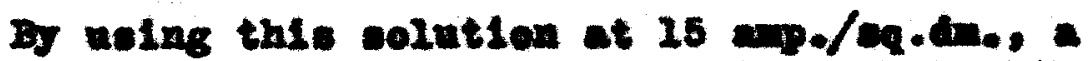
bleck depostt was obtalned which gave qualltative teete for both alekel and chroniw. This beth indieated that the tro matale could be ofmitanecusly doposited Irem an esta bath. The renaluder of the work wes done, ueling this bath and raxylne the concentretions and operatine conditione.

\section{MWARTIS AUT APPARATUS}

Steak solutions were prepared centaining $\mathrm{HLSO}_{4}-$ $\mathrm{IICl}_{2}$ and $\mathrm{CrO}_{3}$ in coneentrations creater than env which wexe to be uned in the Investiontion. The alekel bath centalnod $\mathrm{HISO}_{4}-500 \mathrm{~m} . / \mathrm{L}$. and $\mathrm{ILCl}_{2}-30 \mathrm{m.} / 1$. and the ohroniw beth contained $\mathrm{CrO}_{3}-500 \mathrm{~cm} / \mathrm{s}$.

The $\mathrm{ILSO}_{4}$ we prepared by rearyetalilutig a colution of toehnieal $\mathrm{FiSO}_{4}$, and the $\mathrm{HLCl}_{2}$ wan prepared by the setion of coneentrated HCl on C. P. H1CO . After setion had cessed, the colution wes eviporated to drywen. Aleselved and reeryotalliged to rewove the axpese HCI, which would tend to make the aixed plating bath wore ast.

The platine solutions were andreod soparately to deternive the wetal centent. The ehronim analyals res ande rolwatriealy by ueling $K I$ and titrating the 


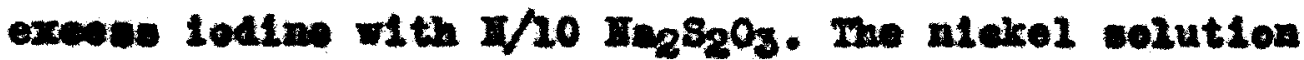
wa ceterninod by the potassiva ejanide wothod. These methode were earried out as direeted by "Seott's Technien lethode of Analysis". The analyeos showed:

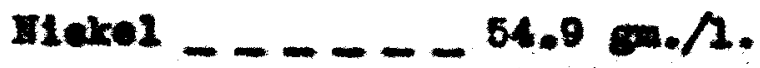

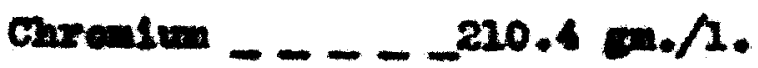

An atterpt to determine the pH of the plating bath by eleetrometrie titration, uolas the quimbrirone electrode, proved unvecessiral sinee the otrons concontration of chroule ecle descupoend the quinhrdrone. Indleatere were not held preatieal, due to the Arril red oolor of the colution, which would cally wack an eolor change in the indieator.

The eolutions ueed durine the inrestigetion contalnod the rollewing coneentrations:

\section{TABTS III}

sununY OP COCPOSITIOT OP EISCTROLYSIS BATHS

\begin{tabular}{|c|c|c|c|c|c|c|}
\hline \multirow{2}{*}{$\begin{array}{l}\text { Beth } \\
\text { Bo. }\end{array}$} & \multicolumn{5}{|c|}{ Conecntration in crans per liter } & \multirow{2}{*}{$\begin{array}{l}\text { Fat10 } \\
\text { Cxarn }\end{array}$} \\
\hline & $\mathrm{CrO}_{3}$ & $\mathbf{2 1 8 0 4}$ & $\mathbf{4 1 0 1 2}$ & $c x$ & BI & \\
\hline $\begin{array}{l}1 \\
2 \\
3 \\
4 \\
5 \\
6\end{array}$ & $\begin{array}{l}260 \\
200 \\
166 \\
125 \\
125 \\
156\end{array}$ & \begin{tabular}{|l|}
280 \\
200 \\
166 \\
125 \\
245 \\
245
\end{tabular} & $\begin{array}{l}15 \\
12 \\
10 \\
7.5 \\
7.5 \\
7.5\end{array}$ & $\begin{array}{r}108.23 \\
84.18 \\
69.45 \\
52.62 \\
52.62 \\
65.66\end{array}$ & $\begin{array}{l}27.45 \\
21.96 \\
28.22 \\
13.73 \\
26.61 \\
26.81\end{array}$ & $\begin{array}{l}3.83 \\
3.83 \\
3.83 \\
3.83 \\
1.86 \\
2.45\end{array}$ \\
\hline
\end{tabular}

The abowe solutione were uced as a beld to whleh were edded varylns mownte of celd, bege and adition sonts. 
The wethed of anclyele of the depoeste consioted in dissolving the alog in concentreted HCI and dividing the celution inte two portions. one of wich wes tested for niekel, the other for ahrenive.

The qualitative mothod uned for niekel thruout the Imertigetion wa to wake the solution alkeline

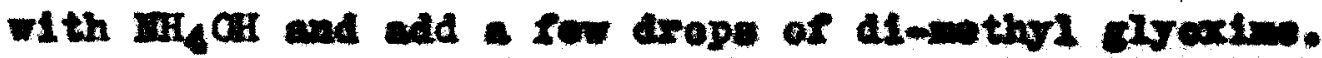
Whon noted, a red prealpltate care en identifleation for alekel. The deteation of emronlun required the axteation of $\mathrm{Cx}^{++t}$ to $\mathrm{Cr}^{+++++t}$. The celution ves made

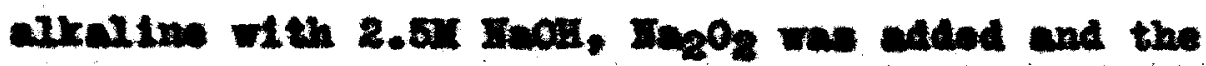
eolution bollod watli a elear ye110r calor appeared. seet1. ald was added and a jellow proetpitate with berium aeetate or bariun ehloride, in an exeene of seatle cold, showed the propeses of ehrentun. Copper and eteol entholes were comerally omployed, and being colvble In HCl, the celution containod not only the eposit bat pert of the bese motel wish interfored

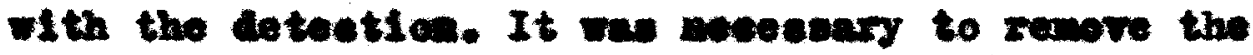
forelge watel before the qualitetive tort wes nade.

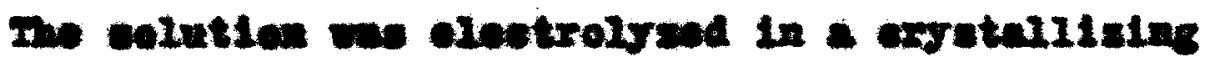

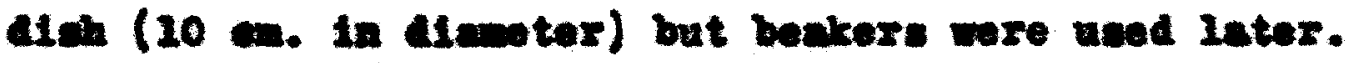
In oxder to sceomodate two and somstimes four anodes 


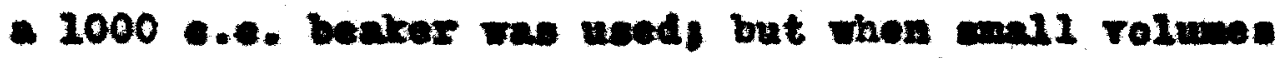
of colution and one mode were belms uned. $400-600$ -. . betrere were entlaratery.

The anodes were of lead approximately $16 \mathrm{aq} \cdot \mathrm{en}$. in ares; and the ateel, cepper end platimm eathodes wer. approximately $25 \mathrm{sq} \cdot \mathrm{cm}$. In exes. The ano cres of cnode and esthode surfaves that is, about 0.1 eq.dm.. was imereed in the solution. In order to malatala equal cument denolties on both.

An Lastmwant bend (FLe. IV) garo complet eostrol of the earrent thar the enodes and eathode and the IR arop exroes the beth. The Inetrument

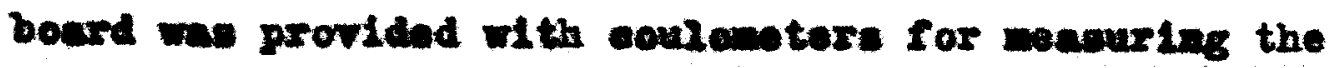
current offioleney and potentionater for deteraining anode and enthede polarination. Manes properties irero net otudied, at the prelininery nature of the work did not juetify these deteringtione melr further otw. howerer, 1. recommonded.

\section{FIXAT GXPERINIATAT,}

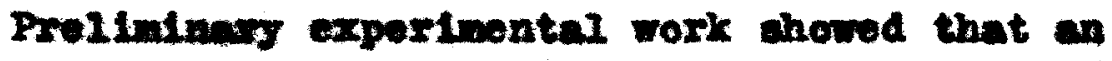

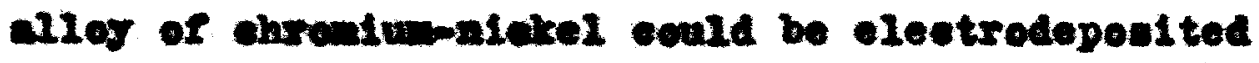

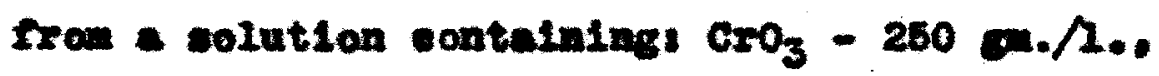

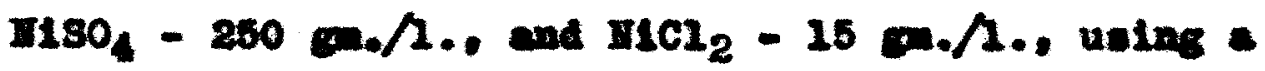


FIG. IV

DIAGRAM OF SIITCHBOARD

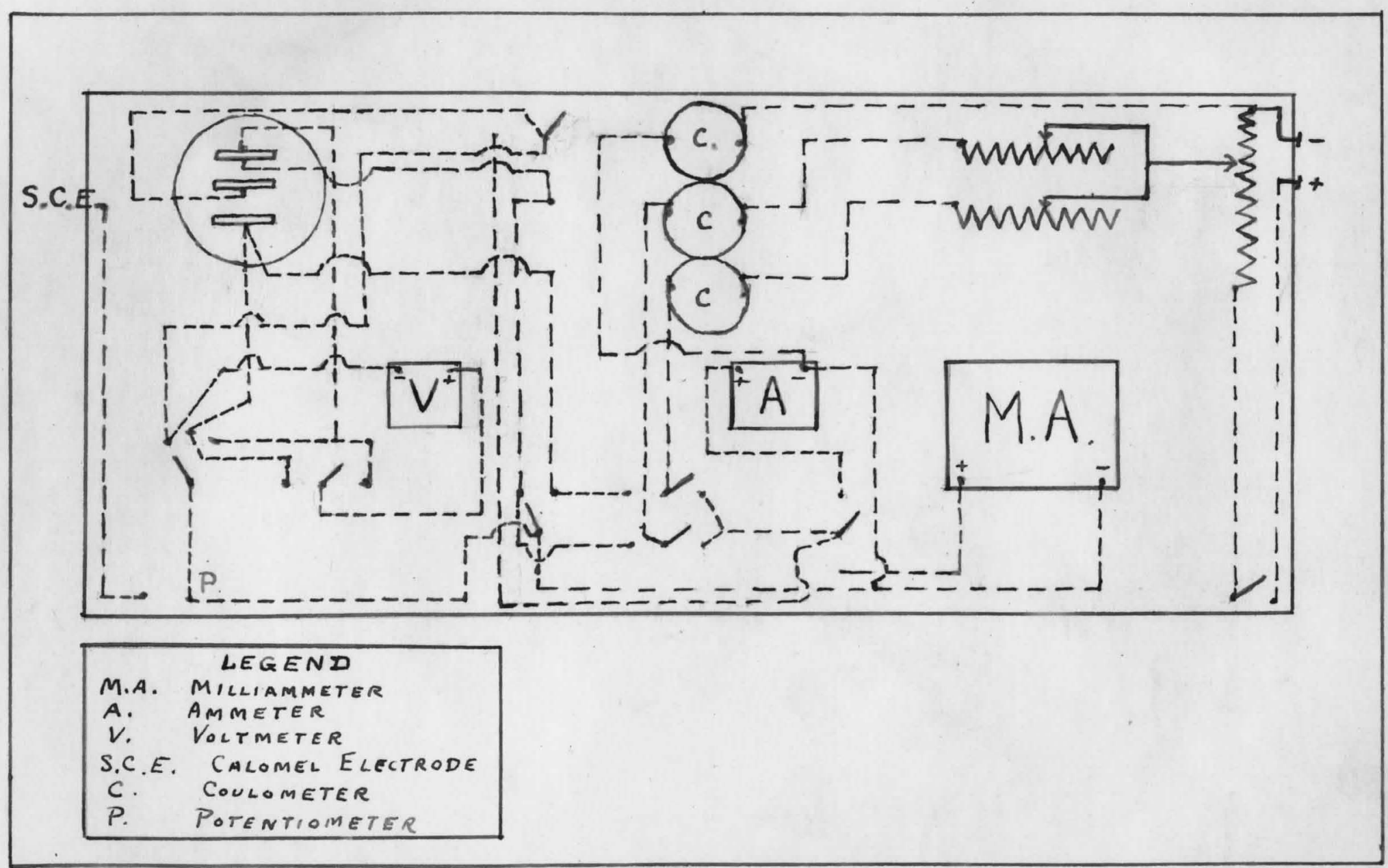


Iosd aode and a eopper eathode, oporating at

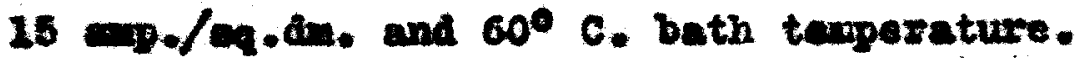
meotrolyais bath of the camposition given in Teble III vere ued. The tine of the electrolysts wes on hour, uniese ethervice noted.

Bath I, cortaining $250 \mathrm{gm} / \mathrm{h}, \mathrm{CrO}_{3}, 250 \mathrm{~cm} / \mathrm{L}$. IISO, and $25 \mathrm{om} / \mathrm{h} . \mathrm{HICl}_{2}$, was operated at $25-27^{\circ} \mathrm{C}$. wher varying conditione of eurrent denoity.

\section{TABLE IV}

EIBEECI ON CATHODS MATHEIATS OY BATH I

\begin{tabular}{|c|c|c|}
\hline $\begin{array}{l}\text { Current } \\
\text { Donol th } \\
\text { app/ent }\end{array}$ & Cethode & Depoeit \\
\hline 5.6 & Iend & olnrentun \\
\hline 20.0 & Iead & chromion-n1akel \\
\hline 4.0 & 1ron & nidkel \\
\hline 5.3 & Iron & nlekel \\
\hline 6.8 & Lron & nlakel \\
\hline 8.3 & 1ron & nlakel \\
\hline
\end{tabular}

Uelng lead eathodes, Cr was deposited; but the dopost wes not adhorent and rery coerwe. Iron eathodes waxe uved to obtaln a brightor curface on the baes weter. end onf niekel was deposited. 
The eano colution was nor noutralsed with FeOH and the bath temperature elevated to $60^{\circ} \mathrm{C}$. The reoults aro show in rable $\mathrm{v}$.

\section{TABIS $\mathbf{V}$}

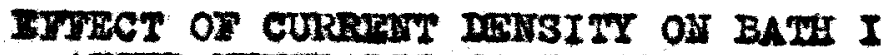

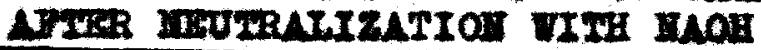

\begin{tabular}{|c|c|c|}
\hline $\begin{array}{l}\text { Cumrent } \\
\text { Danolty } \\
\text { ap/da. }\end{array}$ & Cathede & Depost \\
\hline 15.0 & Pt & olveatum-nLekel \\
\hline 20.0 & Pt & chroniun-niekel \\
\hline 25.0 & Pt & ohromiun-niakel \\
\hline
\end{tabular}

Al though the chromiumntakel alloy was obteined In this weutral welutien, the deposit was rery poor and coaree and was easily peeled from the pletinn. Theve revelte chor that if the soldity is decreaced, Beth I civee depoeits of the alloy of niekel and ahronive. bat the deposits were dull and sough. Those rough doponits succested that too high a soneentration was bolne ased, and Beth II wes prepared.

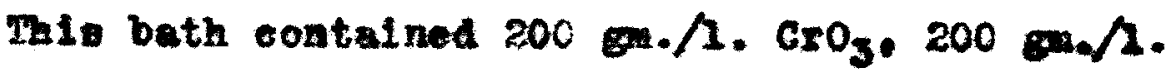
$\mathrm{HSO}_{4}$ and $12 \mathrm{em} / \mathrm{1}$. $\mathrm{HLCl}_{2}$. It was operatod at $30^{\circ} \mathrm{C}$. ent 16 exp./4n.2 Sedim hydrexide wes alded in anall 1neromonte, and Table II gives the remite. 
Thece rocults wow that ehrealu is not dopesited

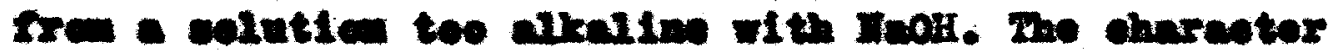
of the depeste was the beet ret obtuinod, being bright

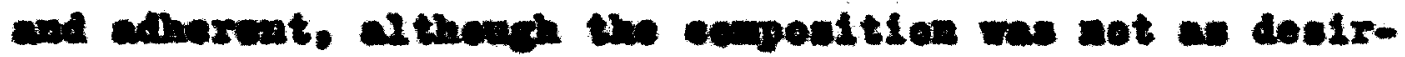
a.:

\section{TUBT VI}

EPHBCT OP INOH OI BATH II

\begin{tabular}{|c|c|c|}
\hline $\operatorname{mog}_{0 .}$ & Cathelo & Bopealt \\
\hline 4.0 & on & Bright In gentex. Wat \\
\hline 6.0 & O. & Bright over awrooe. \\
\hline $\mathbf{1 2 . 0}$ & ca & ht over guxfece. \\
\hline
\end{tabular}

An Inveotigation was mor nade, uning lower conacutration, Beth III, containing $166 \mathrm{gm} \cdot \mathrm{h} . \mathrm{CrO}_{3}$

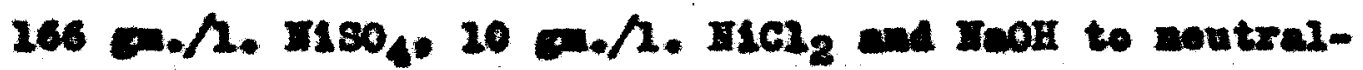
16. the exeese ell. Ints both cere cood jields of chrentu owe the entire range otudiod, but nickel wo env allent at 10 wurrent denattles, but inoreased

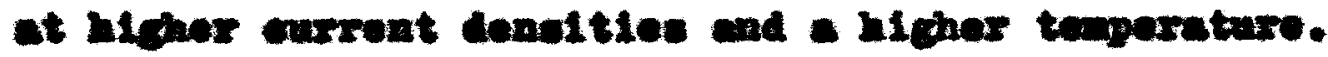

Dis weuld indieate that the onreming is bolng Copelariagd by the nickel and tharefore the allor is copodting at a lower curreat deaclty than would be 


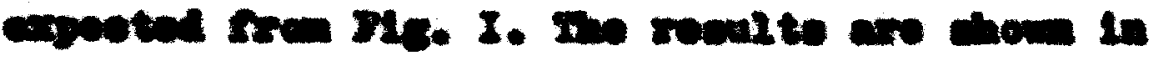
nove ris.

\section{TABI $\mathbf{n x}$}

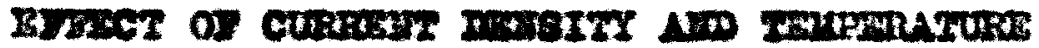

a 247II II

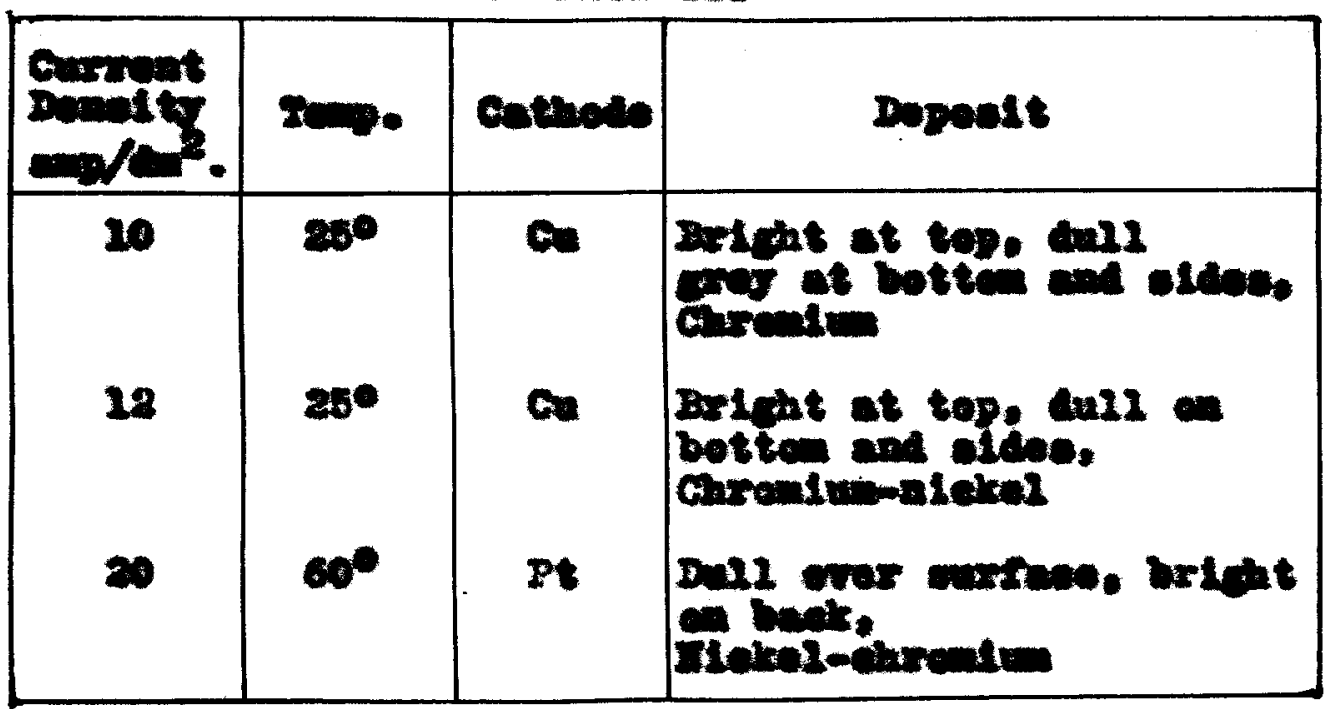

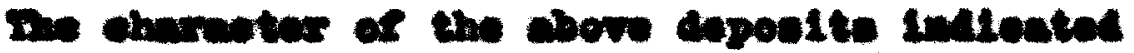
that the colutter we toe cembatrated, and for the

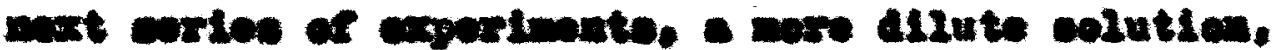

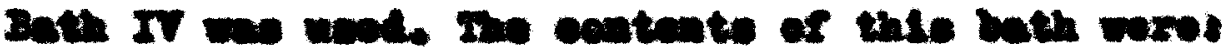

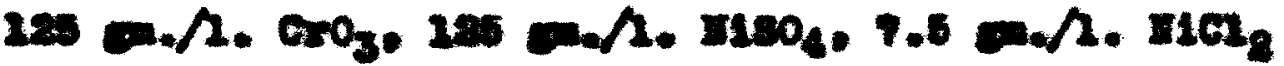

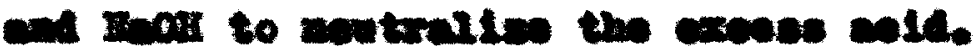

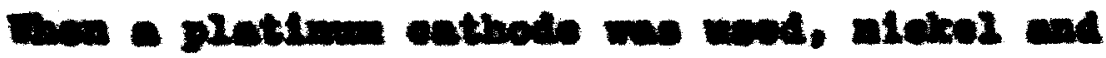

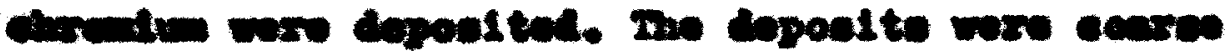

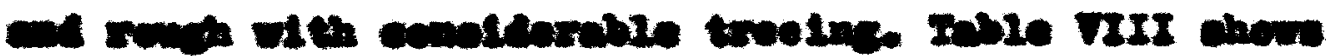

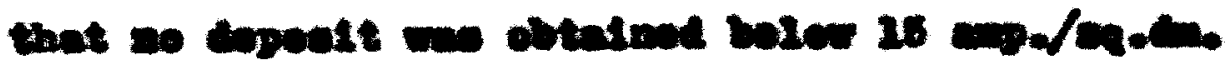

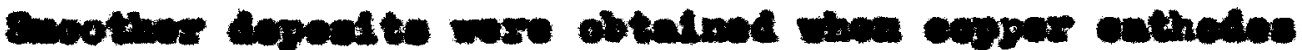

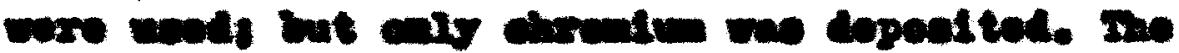

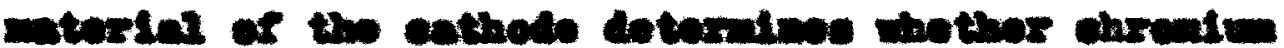


a the al10 N121 be leposited.

TABTR VIII

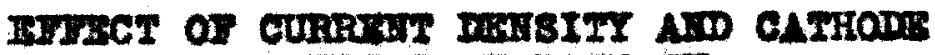

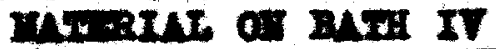

\begin{tabular}{|c|c|c|c|}
\hline $\begin{array}{l}\text { Cunxont } \\
\text { Donglty }\end{array}$ & 200. & Onthede & Dopoest \\
\hline 20 & $60^{\circ}$ & Pt & Io cepost \\
\hline 26 & $60^{\circ}$ & Pt & 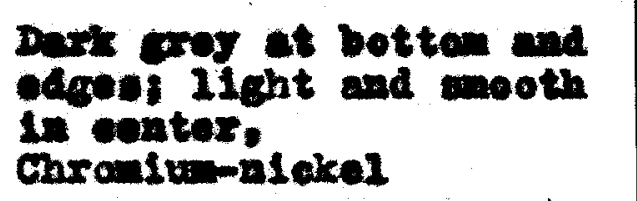 \\
\hline 20 & $60^{\circ}$ & $\mathbf{P t}$ & 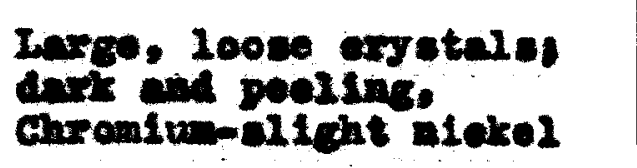 \\
\hline 18 & $30^{\circ}$ & on & 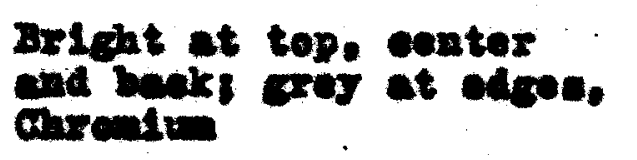 \\
\hline 15 & $30^{\circ}$ & Ca & 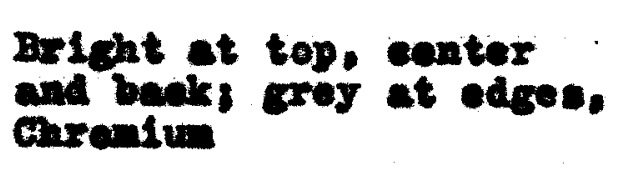 \\
\hline 22 & $60^{\circ}$ & cu & $\begin{array}{l}\text { Bricht, adherent on aldes } \\
\text { end eenter: }\end{array}$ \\
\hline
\end{tabular}

The cone colution, Bath IV, containing $225 \mathrm{mo/}$.

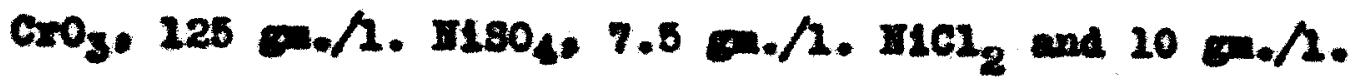

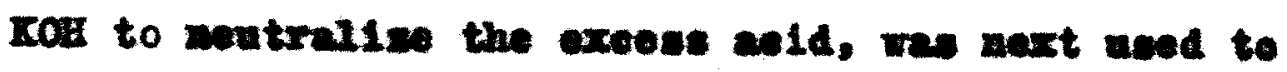
otudy the erreet of temperature on the doposite. Copper exthodes were enod and the colut10n we egitated.

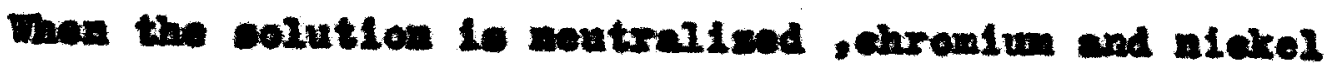




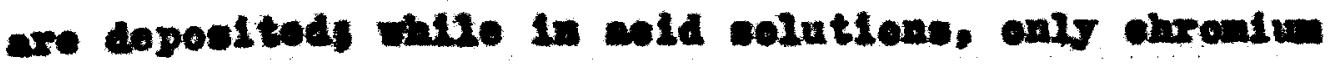
10 plated out at 22 ap./m.4n. and te toperature of $25^{\circ}$ C. It is wen tron Fole IX that when the temper.

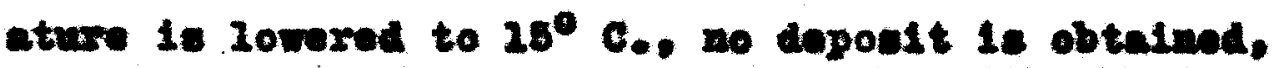
and at $50^{\circ} \mathrm{C}$. the dopoest is brom and earreded.

\section{TABIT IX}

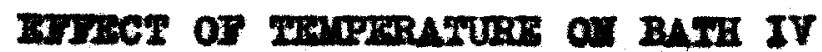

\begin{tabular}{|c|c|c|}
\hline ourrent & Teing. & Dopoat \\
\hline 22 & $16^{\circ}$ & $\begin{array}{l}\text { Depoalt at tept brown exust } \\
\text { bolow. }\end{array}$ \\
\hline 12 & $25^{\circ}$ & 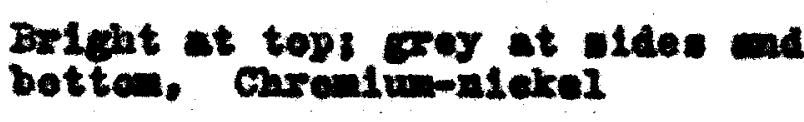 \\
\hline 12 & $80^{\circ}$ & $\begin{array}{l}\text { Brown, eorroded depoelti } \\
\text { nowingtelile }\end{array}$ \\
\hline
\end{tabular}

In order to deterine the offeat of $\mathrm{EeOH}$ on the depesition of the aller. 5 on. Inoremente of $\mathrm{YaOH}$ wore edded to Bath IV. Copper enthodes were uned and

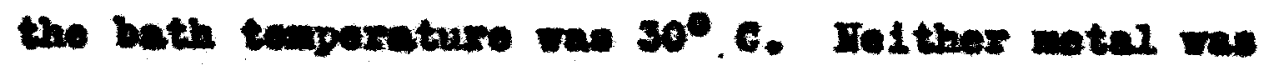
coponted rrom the alkaline colution, contalning noxe than $20 \mathrm{gm}$. IaOH $/$. Velng $10 \mathrm{gm} / \mathrm{h}$. and a enrrant denolty of 12 ap./eq.on., the depoeit was brient, except aroun the botton and edges, where it wa -11cht15 grey. The niakel content was rexy 100 and sanetinos zaking. 
TART $\mathrm{X}$

HFrec or Door or BAM IV

\begin{tabular}{|c|c|c|}
\hline $\log$ & $\begin{array}{l}\text { Curnent } \\
\text { Denott } \\
\text { anp/an. }\end{array}$ & Duposts \\
\hline 5 & 15 & 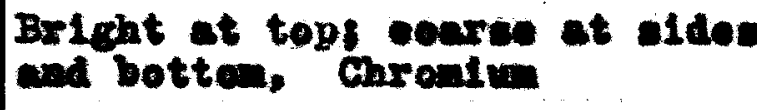 \\
\hline 10 & 12 & $\begin{array}{l}\text { Bright at top and conter } \\
\text { ellont crey doposit at botton, }\end{array}$ \\
\hline 15 & 12 & 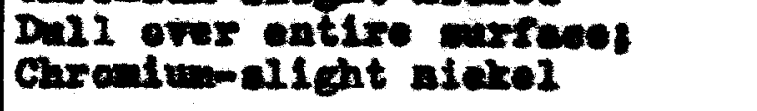 \\
\hline 20 & 12 & Io deponit \\
\hline 25 & 26 & II. depost \\
\hline
\end{tabular}

The aane celution wes ueed in the noxt eet of experinante, except that $15 \mathrm{gm} . / \mathrm{h}$. HCL pere edded to bring the welution beak to a meutral polut. Bath IV now centrined $225 \cdot / 2 . \mathrm{CrO}_{3} \cdot 125-. / 2 . \mathrm{ILSO}_{4}$.

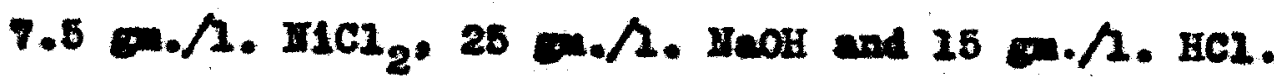
Copper eathoden were used and the colution wos epitated eurine operation.

The regulation of hydrogen lon concentration

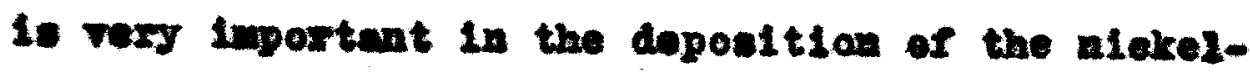
ohrentw ales. It was found that the moutrallead

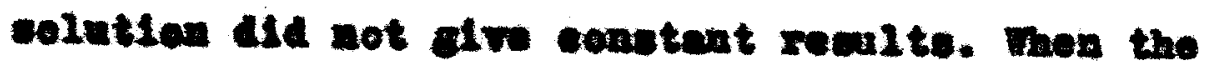




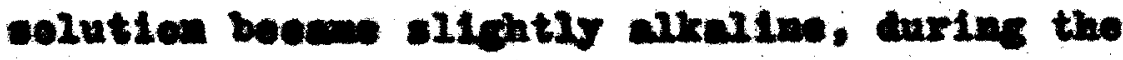
coures of lopositien, - brom arust wes the umal reanits although in come caces, no dopoelt was forwed. This was attributed to the formation of bacle eal to or $\mathrm{Cr}(\mathrm{OB})_{3}$ at the eathode. Mon the solutlen was alighty acid, depoelte of the allor were obtalmed, but the curface was rouch and peeiling or - dull, coerse cooy. It Fll be noted in Inble II that this beth doos not reacin constant at hichor temperetures. At $5^{\circ} \mathrm{C}$. the deposite beeome bromn, rough and unoren.

TBT. XI

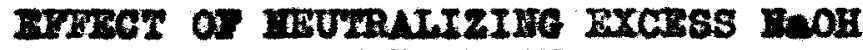
III BATH IV

\begin{tabular}{|c|c|c|}
\hline $\begin{array}{l}\text { Gurrent } \\
\text { Dongit }\end{array}$ & Tenp. & Dopoest \\
\hline 12 & $30^{\circ}$ & 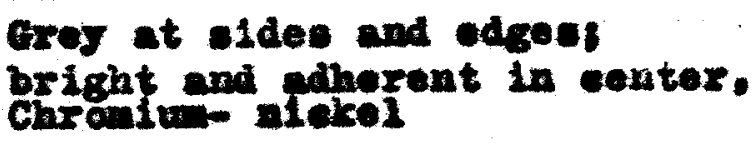 \\
\hline 15 & $30^{\circ}$ & 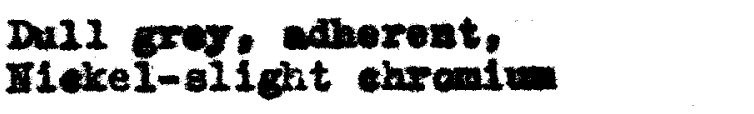 \\
\hline 20 & $30^{\circ}$ & 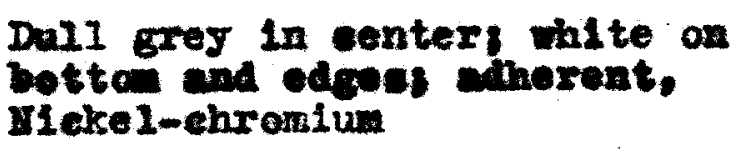 \\
\hline 12 & $45^{\circ}$ & 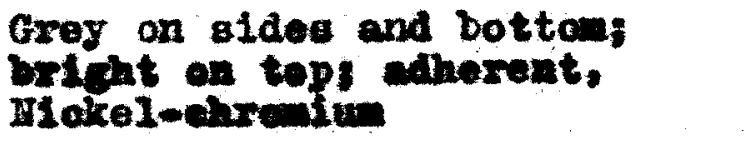 \\
\hline 16 & $45^{\circ}$ & $\begin{array}{l}\text { Grey in eenter; brown on oldes } \\
\text { and botton. Rough, uneven. }\end{array}$ \\
\hline
\end{tabular}




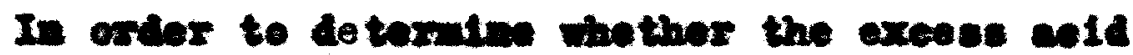
was the cotorrent sactor in the aickel doposition, a opeelal expeximont was wade ucles Bath IV, opex-

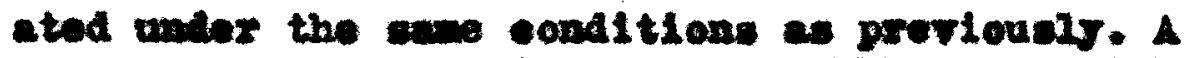
temperature of $30^{\circ} \mathrm{C}$. we malntalmod in a water bath, and coppor eathodes were used. ECI wes added In Inerements up to $100 \mathrm{mon} / \mathrm{h}$. and the welution was ard tated.

TLBLE XII

HTIECT OP HCA OI BATH IV AT VARIOUS CURRRAIT DEEISITIES

\begin{tabular}{|c|c|c|}
\hline Hod & $\begin{array}{l}\text { Current } \\
\text { Dongl t } \\
\text { app/dic. }\end{array}$ & Depost \\
\hline 30 & 12 & Deil whites Chramiun \\
\hline 30 & 15 & Dull gres: Chromiun \\
\hline 48 & 15 & Il ght greys Chraniu \\
\hline 60 & 20 & Dull grey; Chronium \\
\hline 75 & 15 & Dall white: Chroniun \\
\hline 100 & 25 & Dull grey: Ahromitun \\
\hline
\end{tabular}

Table XII shows that, In exeess HCl, only chroniun is deposited. It was conoluded that the componition of the deposit ras in 1 large mannor deternined by the soldity of the electrolyalo bath. When a solution containing excess HaOH was used, the dopent to were spongy eruote and nom-notallie. 
The sdation of HCI in mell quentities resultod in conorent entalle deposite.

sinoe the conditions ceome to faror chromiu depoeltion over niekel dopostion, Bath $V$ weo prepared, containing 245 . IISO 125 en. $\mathrm{CrO}_{3}$, and $7.5 \mathrm{cos}$. IICl$_{2}$ per 11 ter. The Crill ratlo was now 2.1 Instead of 3.8:1 a bafore. Orex a range of curront densitios fren 12-20 en./eq.dn., the solution now ylelded any aiekel in good anounte, but the surface was dull though almorent. Durine the electrolyels, the bath teaperature wa mointelined at $25^{\circ} \mathrm{C}$. and the eathodes rere of eoppor.

TABISR XIII

BYTECT OF CURREAT DEASITY OI BATH $\nabla$

\begin{tabular}{|c|c|c|}
\hline 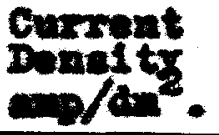 & Tonp. & Depoelt \\
\hline 12 & $25^{\circ}$ & Dall creys nickel \\
\hline 25 & $25^{\circ}$ & $\begin{array}{l}\text { DuIl on front; brient on beeks } \\
\text { Biekel }\end{array}$ \\
\hline 20 & $25^{\circ}$ & $\begin{array}{l}\text { Dull grey, adherent; } \\
\text { MLekei-eilght onrealum }\end{array}$ \\
\hline
\end{tabular}

In oxder to erfeet enronium deposition frem thit bath, when sready jieled goed nlokel doposite. Bath VI wo wood, containing $26 \%$ edditiond $\mathrm{CrO}_{3}$.

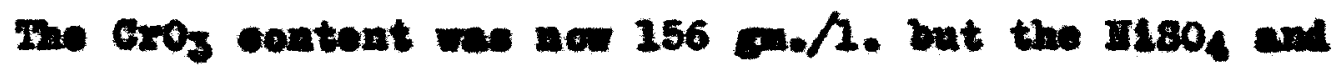




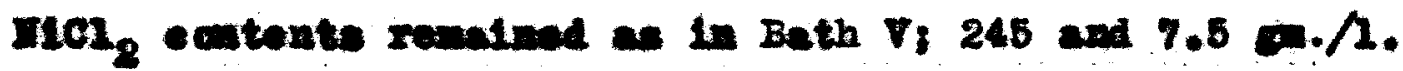
reupetiraly. The notel ratio in the colution we now 2.58h. Iore condetent remate were obtalined with this bath then with an previously used that is, the eapoctiten of the depost wa not changed by all at ehange in entalty.

TABIS XIV

HFTECT OP CURRTAT DESSITY OI BATH $\mathbf{n}$

\begin{tabular}{|c|c|c|c|}
\hline $\begin{array}{l}\text { Curront } \\
\text { Dansity } \\
\text { enp/on. }\end{array}$ & Temp. & Cathode & Depon $1 t$ \\
\hline 16 & $250^{\circ}$ & P: & 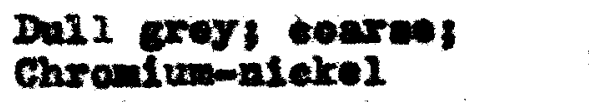 \\
\hline 15 & $25^{\circ}$ & $\mathrm{Ca}$ & $\begin{array}{l}\text { Seoth whites adherents } \\
\text { Wickel }\end{array}$ \\
\hline 20 & $25^{\circ}$ & $\mathrm{Cu}$ & 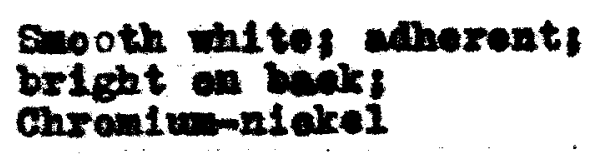 \\
\hline 20 & $25^{\circ}$ & $\mathrm{Cu}$ & $\begin{array}{l}\text { Sooth wites adherents } \\
\text { Chromilu-niekel }\end{array}$ \\
\hline
\end{tabular}

It wes found that hichor ourrent denelties were required to depoeit the ellor than with other beths. 1 enoth, fino-grelned dcpostt wes fommd after 6-10 nimates lweralon, while after ruming the bath for a poriod of tro houxs, the ourfese of the motel was etresked wth groy ad precented a dull appearanoe. 
Beth $\mathbf{I}$ wes agleted wile in operation and, und tre provlous baths, a more eren dietributles of wotal on the sathode wes efrected. Bath VI I thout egitation, gave dopoulte wish were conres at the edger with conoldorable troelng. vale was romodied is actition, shile is provious colutions. agltation bad little effeot. The cosrwonose around the odges and botten was probably due to the mall bath used.

Further experinonte performod undor the bbove ocadtions, remited in abrorent, though not Iustrous. Copoedte.

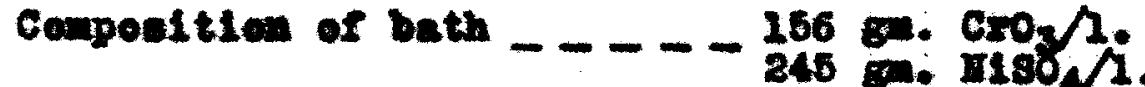

$$
\begin{aligned}
& 7.5 \text { an. } \mathrm{MLC1} / \mathrm{s} \text {. }
\end{aligned}
$$

Curront donelty $\ldots \ldots \ldots \ldots$, 20 andeq.dn.

Tomperature $\ldots \ldots \ldots-\ldots,-32^{\circ} \mathrm{c}$.

B.II.I. arrene eell_ $\ldots-\ldots,-6.7-7$ rolts

Cathode_

Anode - $-\ldots,-\ldots, \ldots$ lead

Tin of depost _ $\ldots$ - $\ldots$ - 120 mimtes

Anvivele of Dopostt?

$$
\begin{aligned}
& \text { Iiteke1 _ _ _ } 63.6 \% \\
& \text { Caromiun _ _ - 36.4\% }
\end{aligned}
$$


Gomprostar

mis invertigntion ahow thet als ar

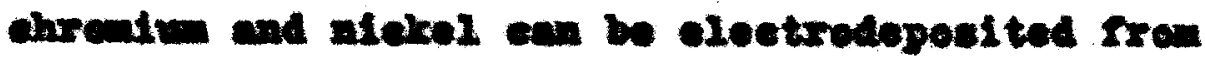

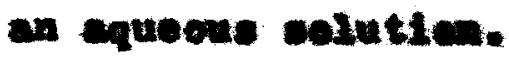

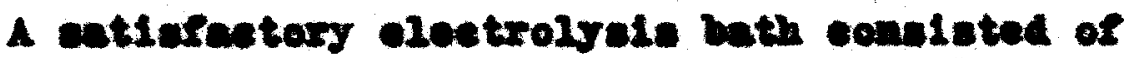

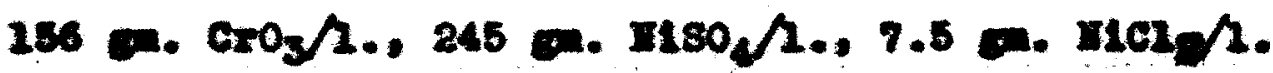

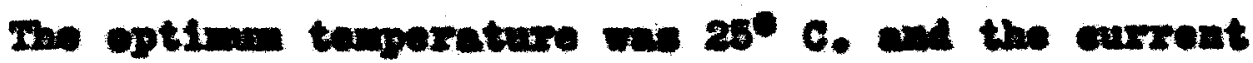

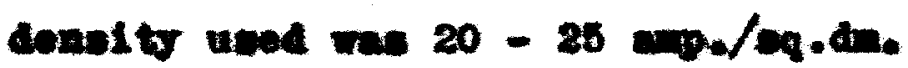

The romating alere wre, in gonoral, grey in

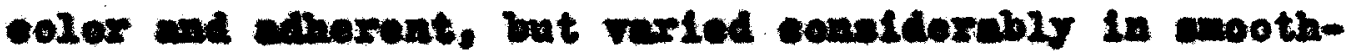

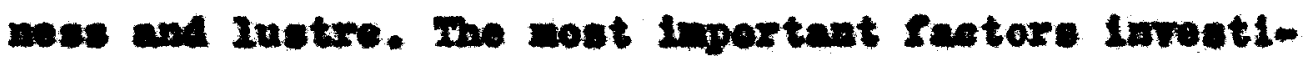

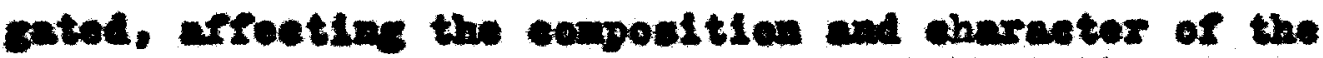

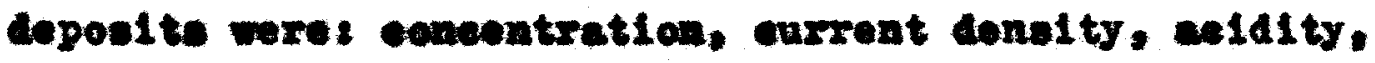
temporatare and bare motel.

(1) Conatrith. Eleetrolrole bathe contaluins

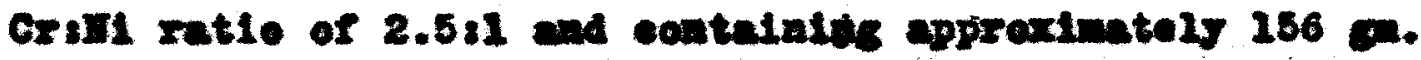

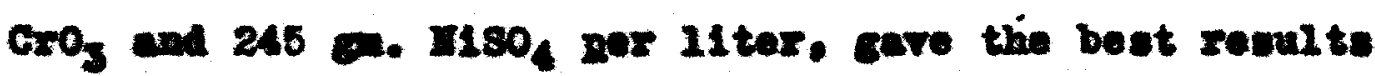

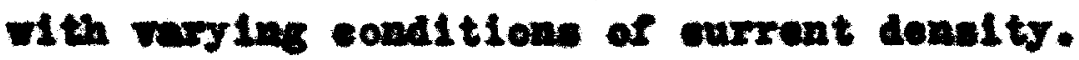

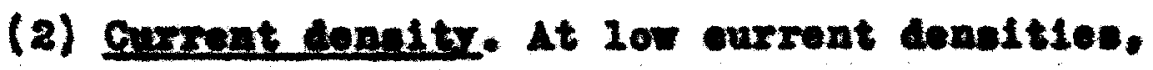

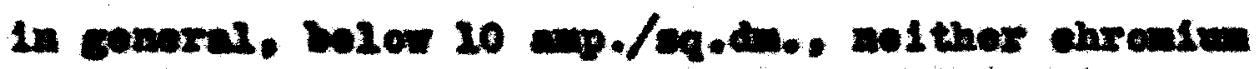
nor aldrel are deponttod srem this beth. Iren $10-20$

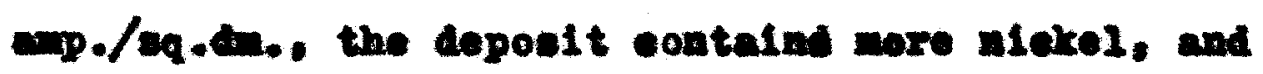




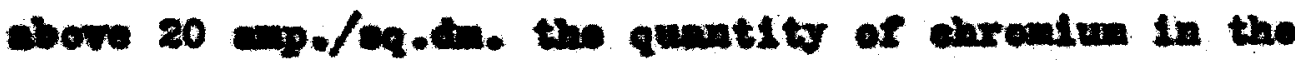
copeste inoreacos.

(3) Adidity. The depoelte centalnod no nlakel from solutlowe to wieh iditionel oold was eddod.

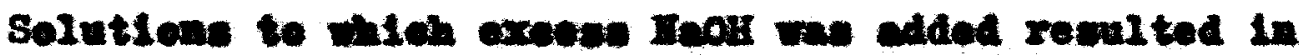
the coposition of melthor motal. The bont results were obtalned, when the colution was prepered by dionolving and alxine the earte.

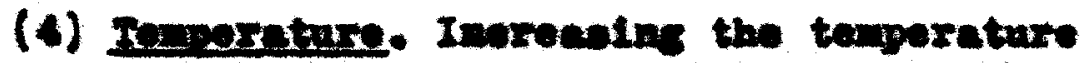
has but 11tile effeet on the ecmpestition of the depoeite.

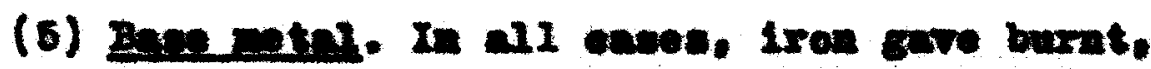
rouch deposite, and often hindered ehromiwe deposition. Plattmen forered apostion of both notals but gare

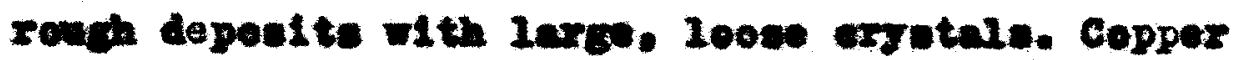
was round to give better depoelte under ldentieal conditione then the other neters stralied. 


\section{BIBLIOGRAPHY}

1. Hineling and Cooley, Trane. An. Blectroahan. Soe., 48. 61 (1925)

2. P. Yartao, Brit. 24,562, Iov., 1911 (C. A. Z. 1446)

3. Kronann, Sechy and Mase, Manatah. 31. 1757-1809 (c. 1. 8. 896)

4. Anow, Brese Dorle 5. 208 (C. A. 3. 2668)

5. Sohook and H1rwoh, J. Anox. Chom. Soe. 29, 314-21 (1907)

6. Leuehter, Br1t. 9,075; Apx., 1912 (C. A. Z. 3279)

7. Plelde, Prineiples of Flectrodeponitien, pe. 263, Langiane, Green \& Ce., Lobdon (1911)

B. Natt, and Philipe, Electrodeposition and Electrorefining of Hetale, ps. 399, Croubs Iockwood \& Sons, London (1911)

9. Beed, Brit. 9,612, 4pr., 1912 (C. A. 1. 3279)

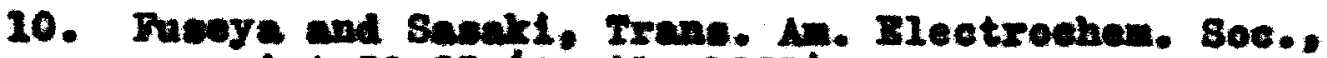
preprint 59-23 (Apr11, 1931)

11. Stemens and Hal oke, Brit. 286.457 (1927) (C. A. I. 3279)

12. Carreth and Curry. Jour. Phye. Chem. 9. 353 (1905)

13. Sargent, Trans. An. Eleetrochem. S06. 37, 275-92 (2920)

14. Sehveldowind. Fng. Receareh Bull. Ho. 8, Unireralty of Hehlean, Ior., 1927

15. Mavie, Trane. An. Hleetroehen. S00. 9, 212 (1906)

16. Brans, Hetals and Yotall1e Cempounds, p8. 325 , Iongenas, Ioladon (1923)

17. Hellor, A Comprehenalve Treatice on Inorcenle and Meoretien Chenietry. Vol. X. pe. I62s Lomonans. Green \& Co., Lendon (I03I)

18. Blum and Hegboen. Prinelples of Flectroplating and Eleotroforning, Ps. 256 , HeGrem-H111 Co., I. Y. (1930) 


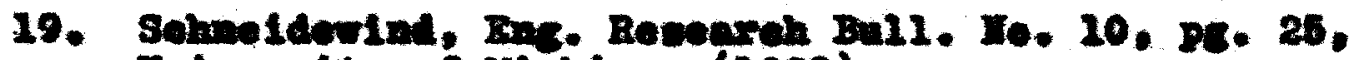
Untverat ty of Michlgen (1928)

20. Iakrene, Trane. An. FIectroehom. Soc. 53, 49 (1928)

21. Liebreleh, 2. Floktroeben. 29, 208-10 (1923) (c. 4. 17. 2836)

22. Grabe and Brelt1ngar, 2. Hektreaher. 33, 112-4 (c. A. 31. 1918)

23. Sargent, Trans. An. Electroehen. Soe. 37. 492-4 (2921)

24. Phillipe, Trans. Am. Electroehom. Sec. 58, 387 (1930)

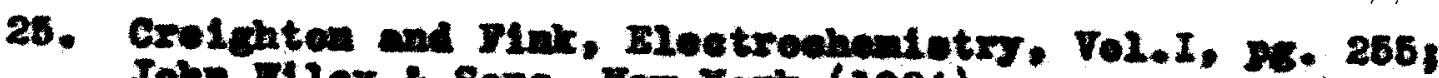
John Tlley SORo, Bow York (1024)

26. Theopen, Thooretienl and Applled Flectroohondstry. pp. 119-21, Haulilen Co.. Hew Yori (1925)

27. Blu an Haring, Trane. Ar. Eleotrochen. Soe. 10.

28. Watte, Trens. An. Blectrochom. Soe. 52, 182, (1927)

29. Selwarts, Trane. An. Fleotrochon. Soe. 4․ 451 (1923)

30. P2weet and Bonnet, V. S. Patent 526,114 (1894) (Trans. As. Bleotroehom. Soc. 53, 457 (2928))

31. Intermational Critieal Tables, Vol. II, pg. 432 , 1et. RAltion 1927 , MeGram-Hili Co, Iow Yort. 